\title{
Konsep Diri Perempuan Pelaku Pembunuhan
}

\author{
GENNY GUSTINA SARI ${ }^{1}$, WELLY WIRMAN ${ }^{2}$ \\ ${ }^{12}$ Fakultas IImu Sosial dan IImu Politik, Universitas Riau, Kampus Bina Widya \\ Jl. Hr. Soebrantas KM. 12.5 Simp. Baru Pekanbaru - 28293 \\ ${ }^{1}$ gennygustina@gmail.com, ${ }^{2}$ wellywirman@yahoo.com
}

\begin{abstract}
Abstact. Women as perpetrators of murder is an interesting phenomenon to be studied, given the stigmatizing between men and women do in the community. Combining the law, psychology and communication, the authors try to see how the concept of self-female murderers in prison. Results of the study revealed that women prisoners perpetrators can be categorized into two: as the main actors and Performers accompanying. The main culprit is the women who commit murder with his own hands and actors accompanying a woman who was involved in the murder, but no loss of life with his own hands. The concept of self-murder convict women as main actors tend negative, compared with female inmates as actors accompanying murder, as seen from the object of their remorse. Inmates main perpetrator blame yourself for what happened to them at this time, while the inmates as actors accompanying tend to blame others that cause it to inmates.
\end{abstract}

Keyword: self concept, woman, murder.

\begin{abstract}
Abstrak. Perempuan sebagai pelaku pembunuhan merupakan fenomena yang menarik untuk diteliti mengingat adanya streotip antara laki-laki dan perempuan di dalam masyarakat. Menggabungkan sisi hukum, psikologi dan komunikasi, penulis mencoba melihat bagaimana konsep diri perempuan pelaku pembunuhan di dalam penjara. Hasil penelitian ini mengungkapkan bahwa narapidana perempuan pelaku pembunuhan dapat dikategorikan menjadi dua, yaitu sebagai pelaku utama yakni perempuan yang melakukan tindak pembunuhan dengan tangannya sendiri dan pelaku penyerta merupakan perempuan yang ikut terlibat dalam tindak pembunuhan tetapi tidak menghilangkan nyawa dengan tangan sendiri. Konsep diri narapidana perempuan pelaku pembunuhan sebagai pelaku utama cenderung negatif dibandingkan narapidana perempuan pelaku pembunuhan sebagai pelaku penyerta yang dilihat dari objek penyesalan mereka. Narapidana pelaku utama menyalahkan diri sendiri atas apa yang menimpa mereka saat ini, sedangkan narapidana sebagai pelaku penyerta cenderung menyalahkan orang lain yang menyebabkannya menjadi narapidana.
\end{abstract}

Kata Kunci: konsep diri, perempuan, pembunuhan.

\section{Pendahuluan}

Kartini merintis pendidikan untuk perempuan, dengan maksud agar para perempuan yang pada gilirannya nanti menjadi ibu, dapat mendidik putra-putrinya dengan baik, di samping itu agar perempuan dapat menempatkan dirinya setara dengan pria. Upaya untuk mendapatkan kedudukan yang setara tidak mudah, karena bukan hanya pria yang tidak menginginkan perempuan setara dengan pria, tetapi sebagian produk hukum pun tidak berpihak kepada perempuan. Perempuan untuk mendapatkan kedudukan yang setara harus berjuang dengan daya upaya sendiri, bahkan menyelesaikan masalahnya sendiri. Untuk itu perempuan harus berupaya memberdayakan dirinya agar menjadi mandiri dan tidak hidup dalam ketergantungan di bidang apa pun juga (Supriadi, 2004).

Perempuan dan kejahatan terdengar seperti sebuah kaitan yang ganjil, mengingat streotip perempuan sebagai makhluk yang lemah dan jauh dari image kekerasan dan kejahatan, banyak perbedaan antara lakilaki dan perempuan yang ternyata bukan perbedaan riil, namun lebih sebagai suatu perbedaan yang dipersepsikan. Unger \&

Received: 19 Desember 2014, Revision: 8 April 2015, Accepted: 3 Juni 2015

Print ISSN: 0215-8175; Online ISSN: 2303-2499. Copyright@2015. Published by Pusat Penerbitan Universitas (P2U) LPPM Unisba Terakreditasi SK Kemendikbud, No.040/P/2014, berlaku 18-02-2014 s.d 18-02-2019 
Crawford dalam bukunya Women and Gender (1992: 573), mengutip hasil penelitian yang dilakukan oleh Fodor \& Rothblum, di mana beberapa gangguan dikelompokkan berdasarkan jenis kelamin. Seperti yang diungkapkan Kartono dalam bukunya Psikologi Wanita (1992:23). "Ada hal-hal yang memang sudah melekat sedemikian rupa pada diri pria dan wanita, sebagai contoh macam-macam bentuk tindak kriminal yang diasumsikan pada pria dan prostitusi atau pelacuran pada wanita."

Kenyataannya, perempuan juga berpotensi melakukan tindak pidana pembunuhan dan laki-laki dapat masuk ke dunia prostitusi. Hal inilah yang kemudian memunculkan bias dalam masyarakat. Saat steotip gender masih dirasa kental di beberapa bidang namun pudar di bidang lain, salah satunya pada sisi hukum. Narapidana perempuan pelaku pembunuhan akan dicap sebagai seorang pembunuh terlepas dari kondisi dan motif yang melatarbelakangi peristiwa tersebut. Apakah perempuan yang kemudian membela diri atau melindungi keluarga seperti anak, sehingga tanpa sengaja atau terpaksa membunuh bisa dikatakan pembunuh? Atau perempuan yang tidak mengetahui apa-apa tetapi terlibat dalam sebuah tindak pidana pembunuhan bisa dikatakan pembunuh? Artinya, tidak ada batasan yang jelas tentang defenisi pembunuh itu sendiri dalam hukum dan masyarakat.

Kodrat merupakan ketetapan Allah yang mutlak dan bersifat universal, sedangkan kesetaraan gender merupakan pembagian peran antara laki-laki dan perempuan yang diatur oleh manusia (masyarakat) itu sendiri yang bersifat dinamis, dan sangat mungkin berbeda dari satu masyarakat ke masyarakat lain.

Dalam realita kehidupan, hampir semua tugas gender dapat dilakukan oleh kedua kaum laki-laki dan perempuan (kecuali yang bersifat mutlak, melahirkan misalnya). Namun dalam stereotip masyarakat (terutama Indonesia), masih sering terjadi kesalahan pemaknaan terhadap perbedaan gender sebagai kodrat fisiologis dan biologis, sehingga muncul isu bias gender yang dilatarbelakangi oleh adanya ketidakpuasan perlakuan terhadap kaum perempuan. Implikasi bias gender secara tidak langsung dapat merugikan masyarakat secara menyeluruh. Apabila perempuan diposisikan tertinggal, maka akan sulit bagi perempuan untuk menjadi mitra sejajar laki-laki, sehingga hubungan keduanya akan menjadi timpang. Ketimpangan yang dapat berakibat negatif, selanjutnya dapat dihindari dengan mengisi kehidupan yang "harmoni dalam berbeda" (Rahminawati, 2001).

Smart (1980) mengemukakan dua jenis kejahatan yang dapat dilakukan oleh laki-laki dan perempuan, yaitu: Sex-Specific Offences adalah kejahatan-kejahatan yang pelaku utamanya berasal dari salah satu jenis kelamin saja; dan Jenis-jenis kejahatan yang dapat dilakukan oleh kedua jenis kelamin, baik laki-laki maupun perempuan (Miller, 1991: 158). Boleh jadi, alasan atau motif perempuan melakukan tindak pidana pembunuhan berbeda dengan laki-laki, tapi perempuan yang melakukan kejahatan apapun jenisnya akan dijatuhi hukuman yang sama dengan laki-laki seperti yang sudah diatur dalam Undang Undang Dasar Tahun 1945 Pasal 27 ayat 1 yang berbunyi:

Segala warga negara bersamaan kedudukannya dalam hukum dan pemerintahan dan wajib menjunjung hukum dan pemerintahan itu dengan tidak ada kecualinya.

Jadi intinya, baik laki-laki maupun perempuan akan menjalani hukuman yang sama sesuai dengan jenis tindak pidana yang dilakukan.

Dalam kitab UU Hukum Pidana (KUHP) dijelaskan mengenai kejahatan terhadap nyawa pada pasal 338 s/d 350 serta dikuatkan oleh UU No 40 tahun 2008 tentang penghapusan diskriminasi ras dan etnis. Dalam KUHP dijelaskan, lamanya masa hukuman berdasarka jenis kejahatan atau pembunuhan yang telah dilakukan (http:// hukumpidana.bphn.go.id/babbuku/babxix-kejahatan-terhadap-nyawa/) diunduh pada 29 Mei 2015. Dalam salah satu teori kriminologi, yakni teori differential association oleh Edwin H. Sutherland dan Donald Cressey, dijelaskan bahwa kejahatan dipelajari melalui interaksi dengan orang-orang lain dalam kelompok-kelompok pribadi yang intim. Proses belajar itu menyangkut teknik-teknik untuk melakukan kejahatan serta motifmotif, dorongan-dorongan, sikap-sikap dan pembenaran-pembenaran yang mendukung dilakukannya kejahatan. Asumsi dasar teori ini adalah:

(1) Kejahatan dipelajari, secara negatif ini berarti bahwa kejahatan tidak diwariskan;

(2) Kejahatan dipelajari dalam interaksi dengan orang-orang lain melalui proses komunikasi;

(3) Proses belajar kejahatan meliputi: (a) Teknik-teknik untuk melakukan kejahatan yang kadangkala sangat rumit dan kadang-kadang 
sangat sederhana, (b) Arah, motif, dorongan, pembenaran dan sikap-sikap;

(4) Arah khusus motif dan dorongan dipelajari dari defenisi-defenisi tentang menguntungkan atau tidaknya aturan-aturan hokum;

(5) Seseorang menjadi delikuen oleh karena ia lebih mempunyai defenisi yang mendukung pelanggaran hukum dibandingkan dengan defenisi-defenisi yang tidak mendukung pelanggaran hukum; (6) Pengelompokkan yang berbeda-beda mungkin beraneka raganm dalam frekuensi, lamanya, perioritas dan intensitasnya; (7) Proses belajar kejahatan melalui pengelompokkan dengan pola-pola kejahatan atau anti kejahatn menyangkut semua mekanisme terdapat dalam proses belajar apa pun; (8) Walaupun kejahatan merupakan pencerminan kebutuhan-kebutuhan dan nilainilai umum, akan tetapi tidak dijelaskan oleh kebutuhan-kebutuhan dan nilai-nilai tersebut, oleh karena perilaku yang bukan kejahatan pun merupakan pencerminan nilai-nilai dan kebutuhan-kebutuhan yang sama (http:// tugas-makalah.blogspot.com/2013/05/teoriteori-tentang-kejahatan-dan-penyebabnya. html) diunduh 29 Mei 2015.

Freda Adler (dalam Ollenburger \& Moore, 2002:210) berpendapat bahwa kriminalitas perempuan telah meningkat lebih cepat dari kriminalitas yang dilakukan laki-laki, khususnya pada negara-negara berkembang. Bagi negara-negara berkembang, angka pelanggar kriminal secara keseluruhan untuk periode 1970-1975 kira-kira 1.000 per 100.000 penduduk. Jumlah pelanggar telah meningkat secara tetap dengan angka 1\% setiap tahun. Angka pelanggar perempuan telah meningkat $50 \%$ lebih cepat dari laki-laki. Berdasarkan karakteristik sosial, ditetapkan peran untuk laki-laki dan perempuan yang pantas. Akibatnya timbul asosiasi dunia publik bersifat maskulin dan dunia privat pantas untuk kaum laki-laki, domestik dan rumah tangga bersifat feminin adalah milik perempuan (Sumiarni, 2004: 3).

Ilmu pengetahuan membedakan lakilaki dan perempuan dalam banyak aspek, namun dihadapkan pada kondisi di mana perempuan harus menjalani aturan dan ketentuan yang sama dengan laki-laki. Hal ini menjadi sebuah tanda tanya, saat perempuan menjalani hukuman sebagai narapidana, di mana aturan dan ketentuan disamakan dengan laki-laki.

Hilangnya kemerdekaan hidup dalam lingkungan yang tertutup dengan dunia luar, ditambah lagi terbatasnya ruang gerak para narapidana perempuan, secara nyata memengaruhi perilaku mereka. Hal ini, menurut Sarwono (2001: 89), merupakan sebuah proses alamiah di mana kondisi lingkungan akan memengaruhi perilaku individu terutama dalam hal berkomunikasi dan jika dikaitkan dengan kehidupan para narapidana tersebut, maka perubahan situasi lingkungan kehidupan yang baru di dalam penjara membuat mereka mengalami beragam perubahan perilaku dan keyakinan. Data sementara yang penulis dapat di lapangan menunjukkan jumlah narapidana tindak pidana pembunuhan di Lapas Wanita kelas II A Kota Bandung mengalami peningkatan dari 15 narapidana di bulan Juli dan Agustus menjadi 17 orang Narapidana di bulan September. Satu di antaranya adalah narapidana yang digolongkan sebagai anakanak.

Pelaksanaan pidana penjara dengan menempatkan narapidana perempuan di lingkungan yang terbatas dan pola kehidupan yang dipaksakan akan menimbulkan tekanan-tekanan yang bersifat nonfisik yang memengaruhi konsep diri mereka. Dengan ditempatkannya narapidana perempuan di penjara akan menyebabkan perubahan corak kehidupan yang bersangkutan dan dapat dilihat pada perilaku komunikasi yang terbentuk, paling tidak, mengubah kehidupan yang bebas pada masyarakat kepada kehidupan yang serba terbatas dan dipaksakan dalam lingkup masyarakat narapidana di penjara yang cenderung memiliki muatan kriminogenik.

Hasil pengamatan sementara di lapangan menunjukkan gedung sel dibagi menjadi dua, yakni gedung Anggrek yang diperuntukkan bagi narapidana yang baru masuk atau narapidana yang masih harus menjalani hukuman dalam jangka waktu yang cukup lama. Gedung kedua adalah gedung Cempaka yang diperuntukkan bagi narapidana yang akan bebas atau paling tidak sudah menjalani setengah dari masa hukumannya. Selain itu, pemisahan juga terjadi pada ruang sel narapidana. Ruang sel bagi narapidana (di luar pengelompokan berdasarkan jenis kejahatan) etnis cina dibedakan dengan pribumi, pemisahan ruang sel bagi narapidana berstatus Korve (narapidana yang diperbantukan) juga dibedakan dengan narapidana biasa. Penelitian ini bertujuan untuk megetahui konsep diri narapidana perempuan pelaku pembunuhan,

Penelitian ini menggunakan metode kualitatif dengan tradisi fenomenologis. Penulis menggunakan beberapa teori atau konsep yang dijadikan acuan dalam melakukan penelitian di antaranya Fenomenologi (Alferd 
Schutz), Penjara Sebagai Institusi Total (Erving Goffman), Konsep Diri (Carl Rogers) yang digandeng dengan Teori Identitas (Michael Hect). Penulis menghabiskan waktu kurang lebih 4 bulan di dalam penjara. Penulis bekerjasama dengan pihak Lapas Wanita Kelas IIA Kota Bandung untuk menutupi identitas asli penulis sebagai peneliti dan menggantinya sebagai mahasiswi magang yang membantu pihak Lapas dalam mengecek kondisi sarana dan prasarana serta penggunaannya di dalam area penjara.

Mengingat jumlah narapidana perempuan yang cukup banyak dan kesulitan penulis dalam menemukan objek penelitian, yakni perempuan pelaku pembunuhan, penulis menetapkan beberapa kriteria informan penelitian, di antaranya; Pertama, narapidana perempuan dengan range usia 15-30 tahun. Pemilihan ini ditentukan berdasarkan data di lapangan menunjukkan jumlah narapidana perempuan di Lapas Wanita Kelas IIA Kota Bandung sebagian besar di isi oleh perempuan dengan range usia yang produktif yakni 1530 tahun. Kedua, narapidana dengan masa hukuman yang masih harus dijalani lebih kurang 5 tahun. Hal ini dimaksudkan untuk lebih dapat melihat dan memahami konsep diri mereka yang masih harus menjalani hukuman dalam jangka waktu cukup lama. Dalam artian, konsep diri narapidana yang akan bebas jelas berbeda dengan narapidana yang masih harus menjalani sisa hukuman cukup lama.

Kriteria pemilihan informan tersebut telah menjaring keseluruhan informan dari 17 orang menjadi 10 orang yang sesuai dengan kriteria. Dari 10 orang tersebut hanya 6 orang yang dapat dijadikan informan dalam penelitian ini. 4 orang menunjukkan penolakan saat didekati dan ketidakterbukaan serta jawaban yang tidak lengkap atau bias, sehingga tidak dapat atau tidak memenuhi kriteria untuk dijadikan informan dalam penelitian ini.

Membangun akses dengan informan, penulis menggunakan pendekatan personal terhadap masing-masing informan melalui kegiatan pembinaan yang mereka senangi seperti memasak, merajut,membaca atau mendengarkan musik. Masing-masing informan memiliki hobi dan kesenangan masing-masing karena itu penulis perlu mengetahui mengenai seluk beluk kesenangan mereka dan membangun komunikasi yang lebih intens pada tahap awal hanya memfokuskan pada kegemarangan informan.
Lapas Wanita Kelas IIA Kota Bandung merupakan lapas percontohan di Indonesia, di sini peraturan dan tata tertib lebih tegas dan ketat dibandingkan dengan Lapas Wanita lainnya. Di sini, tidak diperkenankan alat komunikasi apapun, tidak terdapat peredaran uang, benda tajam, peralatan masak, peralatan yang terbuat dari kaca.

Dalam mengumpulkan data di lapangan, penulis tidak diperkenankan membawa alat perekam, alat elektronik dan hanya dibatasi pena dan kertas. Kemampuan mengingat setiap perkataan informan sangat dibutuhkan untuk memudahkan penulis juga membatasi diri hanya mengamati dan melakukan wawancara satu informan dalam satu hari. Tentu saja, penulis juga melakukan validasi data dengan mengulang-ulang pertanyaan sehingga jawaban dan data yang didapat sangat akurat.

\section{Profil Perempuan Pelaku Pembunuhan}

Lima dari enam informan telah menikah walaupun tiga orang dari lima informan yang telah menikah melakukan pernikahan di bawah tangan atau nikah siri. Berbagai macam alasan mereka sehingga memilih untuk melakukan nikah siri seperti kondisi keuangan, kehilangan keperawanan, tidak mendapat restu atau kondisi sebagai istri kedua, hamil di luar nikah dan sebagainya.

Kenyataan ini menunjukkan bahwa kehilangan keperawanan telah memengaruhi konsep diri perempuan pada umumnya dan informan dalam penelitian ini, khususnya. Kondisi seperti ini, di mana perempuanperempuan yang kehilangan keperawanan di usia remaja memiliki kemungkinan untuk menjadi tidak percaya diri ditambah lagi penolakan yang dialami dari keluarga atau pasangan selanjutnya, membawa mereka pada kondisi yang tidak menguntungkan seperti terikat baik secara fisik maupun psikis terhadap laki-laki yang merenggut keperawanan mereka atau malah terjerumus dalam dunia prostitusi karena merasa tidak bahagia dan tidak berharga lagi sebagai perempuan.

Dampak lain yang muncul adalah kekerasan atau pelecehan seksual yang terjadi di dalam penjara dari narapidana senior dan berkuasa pada narapidana baru atau narapidana yang dinilai lemah. Upaya pemenuhan kebutuhan biologis, khususnya bagi narapidana perempuan, memang mengundang pertanyaan bagi penulis. Penjara 
tidak menyediakan fasilitas yang memadai untuk narapidana perempuan yang dikunjungi keluarga, khususnya suami, untuk memenuhi kebutuhan biologisnya menyebabkan terjadi tindakan-tindakan amoral dan susila di dalam lapas. Sebagian besar narapidana menutupi kondisinya atau bahkan menolak untuk membicarakan hal tersebut dengan jujur dan terbuka karena adanya penilaian dari masyarakat bahwa perempuan harus mampu menahan kebutuhan dan keinginan tersebut agar tidak dicap sebagai perempuan binal atau sejenisnya.

\section{Kategorisasi Perempuan Pelaku Pembunuhan}

Penulis membedakan perempuan pelaku pembenuhan menjadi dua jenis, sebagai Pelaku Penyerta yakni orang yang terbukti bekerjasama dan terlibat tindak pidana pembunuhan walaupun tidak menghilangkan nyawa orang dengan tangan sendiri. Sedangkan Pelaku Utama adalah orang yang terbukti melakukan pembunuhan dengan tangan sendiri atau menggunakan alat. Berbagai macam alasan dan motif pembunuhan yang dilakukan, ada yang sengaja dan tidak sengaja melakukan pembunuhan, ada yang spontan dan terencana, ada yang sendirian dan dibantu orang lain. Pembunuhan dianggap sebagai solusi atau jalan keluar dari permasalahan, merupakan alasan atau motif yang sering dikemukakan narapidana.

\section{Konsep Diri Narapidana Perempuan Pelaku Pembunuhan}

Combs dan Soper (Dalam Burns, 1993: 93) membedakan dengan jelas bahwa konsep diri adalah bagaimana individu itu melihat dirinya sendiri, sementara pelaporan diri adalah apa-apa yang secara sukarela dikatakan dan diperlihatkan oleh individu perihal dirinya kepada orang luar. Beberapa orang memandang diri mereka sendiri secara negatif dan yang lainnya melihat dirinya secara positif ataupun boleh jadi di antaranya. Konsep diri merupakan cara pandang atau penilaian seseorang mengenai dirinya. Konsep diri sangat ditentukan dari beberapa komponen yakni komponen kognitif atau biasa yang kita sebut sebagai citra diri dan komponen afektif atau harga diri.

Sebagai pelaku utama, pada umumnya lebih senang menyendiri, dalam kerumunan atau pada saat bergabung dengan kelompok terlihat lebih pasif, tidak banyak bicara dan tertutup. Pada saat mengikuti kegiatan pembinaaan, pelaku utama hampir bisa dipastikan mengambil posisi di sisi pinggir dan belakang. Mereka juga tidak terlalu aktif atau menonjolkan diri di antara narapidana lainnya. Perempuan pelaku pembunuhan yang dikategorikan sebagai Pelaku Penyerta umumnya tidak menunjukkan perbedaan yang signifikan dengan narapidana kasus lainnya. Mereka lebih bisa berbaur dalam kelompok, tertawa dan mengemukakan pendapat, pada

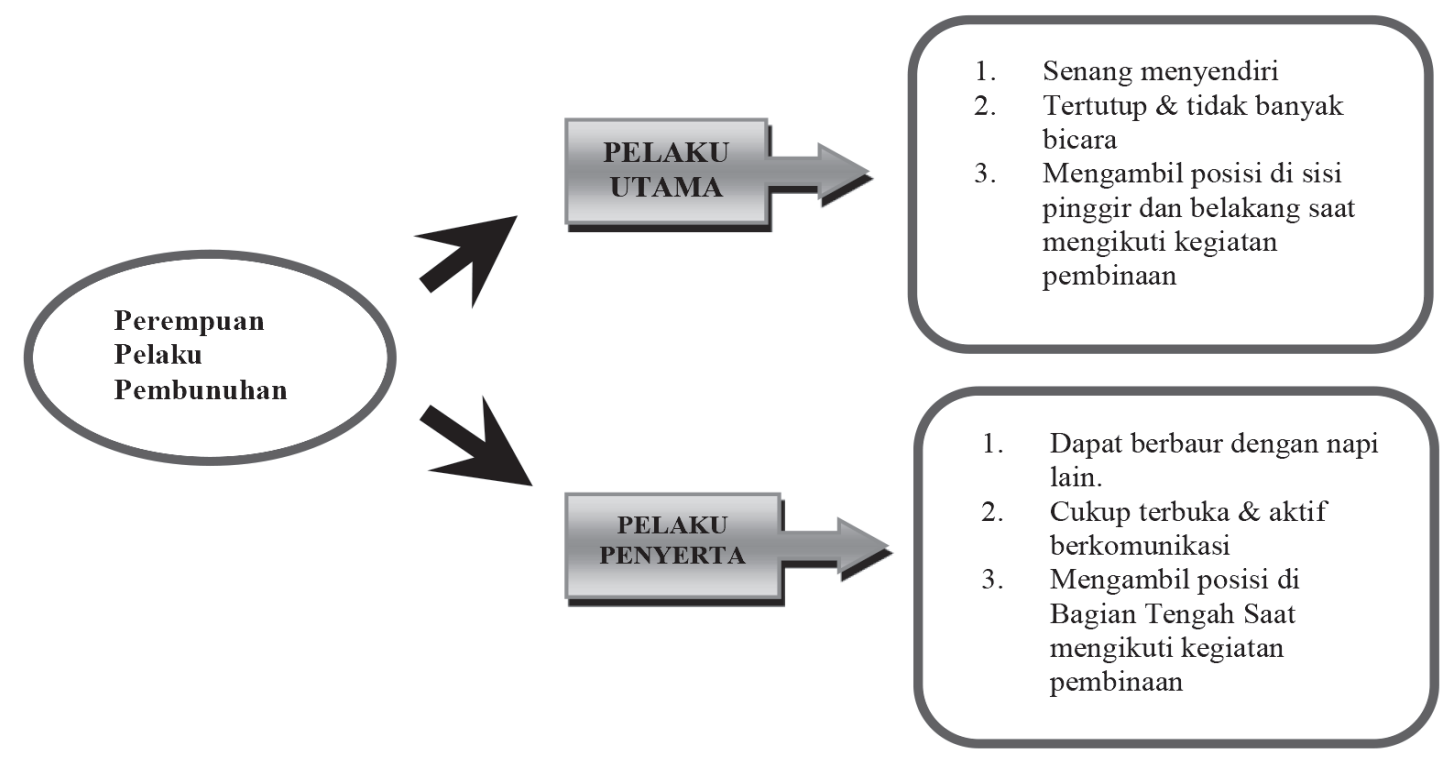

Gambar 1.Kategori dan Ciri Umum Narapidana Perempuan Pelaku Pembunuhan 


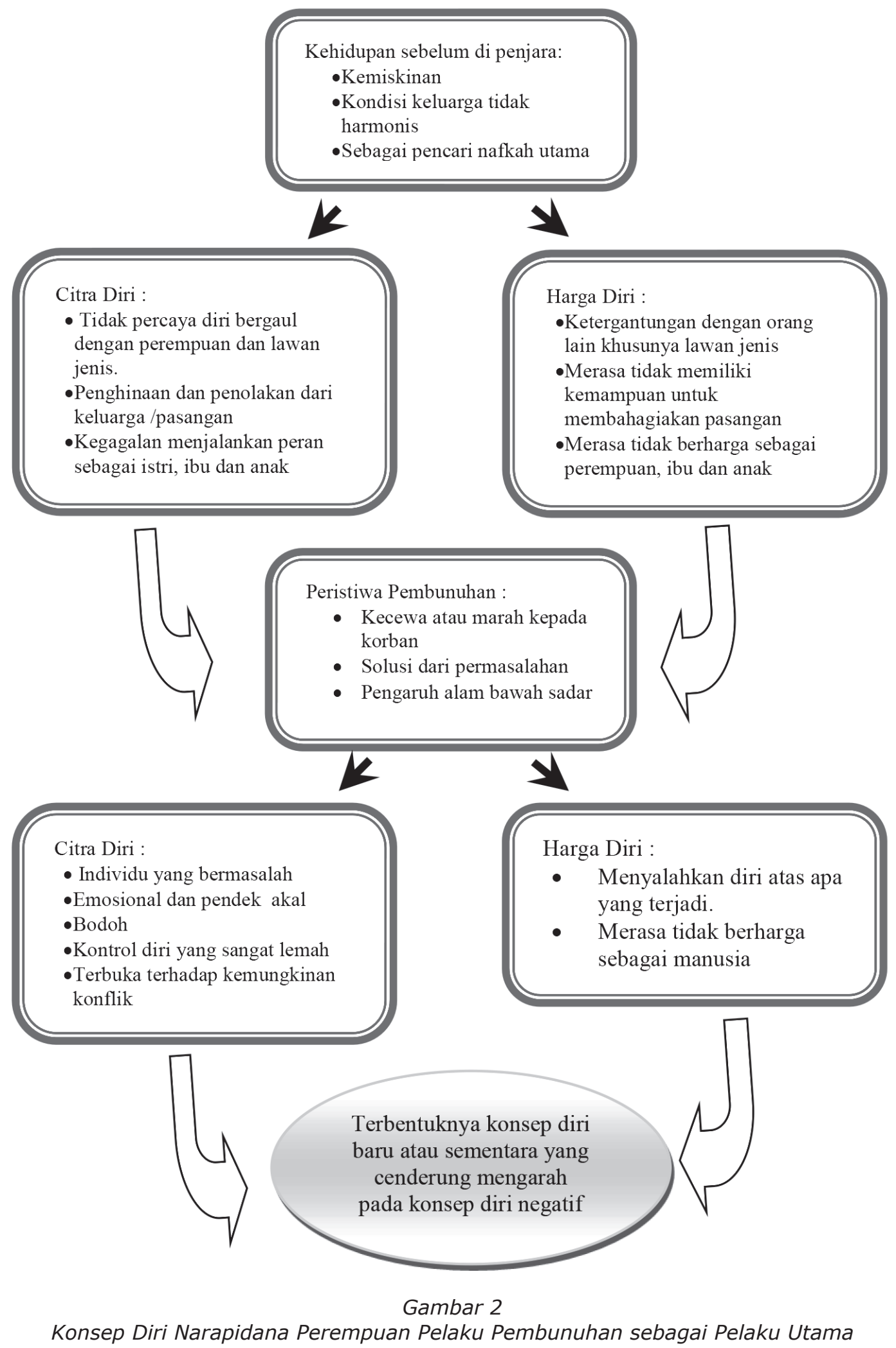

saat mengikuti kegiatan pembinaan pelaku penyerta biasanya berbaur di tengah dan tidak terlalu pasif walaupun mereka tidak ada yang mau mengambil posisi di depan.

Sebagai pelaku utama, perlu dilihat bahwa pengalaman masa lalu atau kehidupan sebelum di penjara memengaruhi pembentukan konsep diri mereka. Faktor seperti keadaan ekonomi, atau kondisi keluarga merupakan faktor-faktor yang memengaruhi citra diri dan harga diri mereka sebagai perempuan. Ketergantungan secara fisik dan psikis terhadap orang-orang di sekeliling mereka 


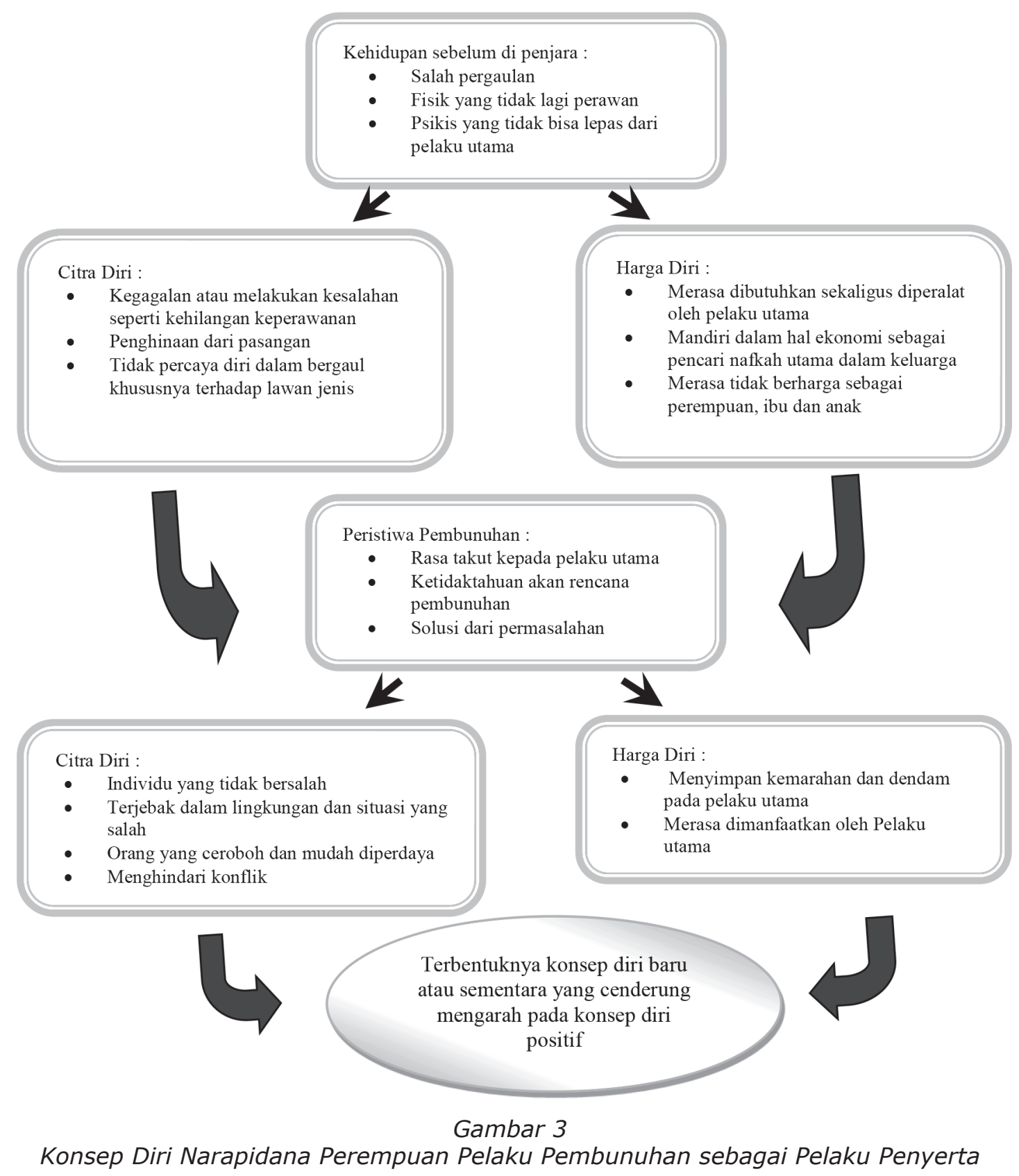

menimbulkan perasaan tidak percaya diri, penolakan, merasa tidak memiliki kelebihan dan kemampuan hingga puncaknya merasa tidak berharga sebagai perempuan, ibu dan anak. Peristiwa pembunuhan di mana mereka berperan sebagai pelaku utama kemudian memengaruhi konsep diri. Penilaian-penilaian mereka tentang diri mereka yang sebelumnya memang telah terbentuk secara negatif akan semakin diperburuk dengan adanya kejadian pembunuhan yang mereka lakukan sendiri. Para pelaku utama menilai tindakan pembunuhan sebagai sebuah kejahatan yang sangat jahat maka secara otomatis mereka akan menilai diri mereka sangat jahat dan tidak bermoral. Di balik sikap menyalahkan diri sebenarnya para pelaku utama telah menyimpan sebuah kemarahan terhadap korban sehingga kemarahan, kekesalan yang dialami, seolah-olah diakumulasikan dan meledak saat menemukan waktu yang tepat sehingga terjadi pembunuhan.

Umumnya, perempuan pelaku pembunuhan sebagai penyerta terjerat kasus pembunuhan berencana. Perempuan dalam kasus ini biasanya bertindak sebagai kaki tangan atau dalang yang merencanakan pembunuhan. Perempuan sebagai otak atau dalang sebuah kasus pembunuhan tidak banyak terjadi, justru perempuan sebagai pelaku penyerta kebanyakan tidak mengetahui rencana pembunuhan atau 
kalaupun mengetahui terpaksa berada di tempat dan waktu yang salah. Umumnya, pelaku utama pembunuhan adalah orangorang terdekat seperti pasangan, orangtua atau sahabat.Tindak pidana pembunuhan yang terjadi biasanya tidak diketahui atau diketahui tetapi diliputi ketakutan akan ancaman pembunuh utama atau bisa saja karena merasa sebagai solusi dari sebuah permasalahan besar yang tengah dihadapinya saat itu. Perempuan pelaku pembunuhan sebagai pelaku penyerta biasanya tidak akan menyesali tindak pidana pembunuhan yang terjadi, melainkan menyesali pertemuan atau awal mula hubungan yang terjalin dengan pelaku utamanya. Perempuan pada posisi ini juga cenderung menyalahkan orang lain atas kondisi yang tengah dihadapinya. Konsep diri yang terbentuk baik baru atau sementara di dalam penjara tidak akan terlalu jauh bergeser atau berbeda dengan konsep diri sebelum mereka di penjara.

Perempuan pelaku penyerta umumnya akan menyalahkan diri mereka karena merasa telah diperdaya oleh pelaku utama. Pelaku penyerta merasa sebagai individu yang terjebak di tempat dan waktu yang salah. Salah satu temuan di lapangan menunjukkan adanya unsur memertahankan citra diri sebelum berada di penjara sehingga muncul upaya untuk meyakinkan lingkungan bahwa merekalah korban dalam kasus tersebut.

Secara sederhana, konsep diri narapidana perempuan pelaku pembunuhan sebagai pelaku utama dan pelaku penyerta dapat dilihat pada bagan di bawah ini:

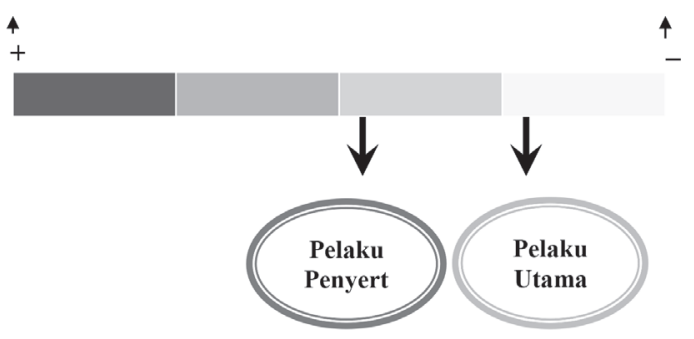

\section{Gambar 4, Posisi Konsep Diri Perempuan Pelaku Pembunuhan}

Gambar 4 menunjukkan posisi konsep diri narapidana perempuan pelaku pembunuhan. Walaupun sama-sama berada pada zona konsep diri negatif tetapi konsep diri pelaku penyerta lebih positif jika dibandingkan dengan konsep diri pelaku utama. Konsep diri setiap individu tidak sama dengan individu lainnya. Hal ini disebabkan karena latar belakang sosial budaya, pendidikan, kondisi ekonomi dan keluarga serta pengalamanapengalaman yang mereka lalui dalam fase kehidupan akan membentuk, mengubah dan memengaruhi konsep diri yang telah terbentuk sebelumnya. Posisi ini bukanlah harga mati dan tidak pula bersifat mutlak. Kondisi ini dapat berubah menjadi baik, atau bahkan menjadi lebih baik tergantung kemampuan masing-masing individu dalam memaknai setiap pengalaman dan menempatkannya dalam proposisi yang sewajarnya dalam kehidupan dan penialainnya mengenai dirinya. Karena konsep diri erat kaitannya dengan bagaimana seorang individu menghargai dirinya kemudian mencitrakan dirinya sebaik mungkin agar terbentuk konsep diri yang lebih positif.

\section{Simpulan dan Saran}

Berdasarkan paparan dan analisis yang disajikan, dapat disimpulkan bahwa konsep diri dibentuk melalui proses panjang dari serangkaian pengalaman yang dipersepsikan dan dimaknai oleh seorang individu. Konsep diri perempuan pelaku pembunuhan terbagi menjadi dua berdasarkan status mereka yakni sebagai pelaku utama dan pelaku penyerta. Sebagai pelaku utama konsep diri yang terbentuk cenderung menjadi lebih negatif dengan menyatakan diri sebagai perempuan bodoh dan pembunuh yang tidak bermoral; sedangkan sebagai pelaku penyerta, konsep diri yang terbentuk lebih positif dibandingkan pelaku utama dengan menyatakan diri sebagai korban dari keadaan serta menyalahkan diri akibat mudah diperdaya oleh pelaku utama.

\section{Daftar Pustaka}

Burns, R.B. (1993). Konsep Diri; Teori, Pengukuran, Perkembangan dan Perilaku. Jakarta: PT. Arcan.

Kartono, Kartini. (1992). Psikologi Wanita, Jilid I. Jakarta: Rajawali Pers.

Miller, JoAnn.L. (1991). Female Criminality in Modren Society. Purdue : In IUC Social Sciences. Purdue University.

Ollenburger, Jane C. \& Helen A. Moore. (2002). Sosiologi Wanita. Jakarta :Rineka Cipta.

Sarwono, Sarlito Wirawan. (2001). Psikologi Sosial, Psikologi Kelompok dan Psikologi Terapan. Jakarta: Balai Pustaka.

Unger, Rhoda \& Mary Crawford. (1992). Women and Gender; A Feminist Psychology. USA: Mc Graw Hill.

Rahminawati, N. (2001). "Isu Kesetaraan Laki-Laki dan Perempuan (Bias Gender). MIMBAR (Jurnal Sosial dan Pembangunan), Volume 1, No. 3, pp 273-283.

Supriadi, W.(2004). Perempuan dan Kesetaraan di Dalam Keluarga. MIMBAR (Jurnal Sosial dan Pembangunan), Volume 20, no. 23, pp 263-273. 